\title{
Syringe Dosing Unit
}

National Cancer Institute

\section{Source}

National Cancer Institute. Syringe Dosing Unit. NCI Thesaurus. Code C48540.

A dosing unit equal to the amount of active ing redient(s) contained in a single syringe. 